\title{
Curly lettuce development, nutrient absorption and salinization tolerance in response to an aerobic biofertilizer produced from agro-industrial residues
}

\author{
Sabrina Magaly Navas Cajamarca ${ }^{1}$, Carlos Eduardo Pacheco Lima ${ }^{2}$, Juscimar da Silva ${ }^{2}$, Italo Moraes Rocha \\ Guedes $^{2}$, Marcos Brandão Braga ${ }^{2}$, Mariana Rodrigues Fontenelle ${ }^{2}$, Cícero Célio de Figueiredo ${ }^{{ }^{*}}$ \\ ${ }^{1}$ Faculty of Agronomy and Veterinary Medicine, University of Brasília, 70910970 Brasília, DF, Brazil \\ ${ }^{2}$ Brazilian Agricultural Research Corporation (EMBRAPA), Embrapa Hortaliças, Brasília, DF, Brazil
}

*Corresponding author: cicerocf@unb.br

\begin{abstract}
Biofertilizers stimulate natural processes to increase and benefit nutrient absorption, abiotic stress tolerance and increased yield when applied to plants. The production of biofertilizers from organic residues is a sustainable way to reduce these materials through recycling. The aim of this work was to define the biofertilization management based on concentrations and doses using a non-commercial aerobic biofertilizer on three newly emerged Brazilian lettuce cultivars. Consequently, this study will help to improve organic lettuces yields in the country. The experiments were conducted in a greenhouse. The soil used for cultivation was a clayey Rhodic Ferralsol. Due to the high electrical conductivity (EC) observed in the biofertilizer a first experiment was conducted to determine the optimum concentration $(0 \%, 5 \%, 10 \%, 15 \%, 20 \%$ and $100 \%)$ for the three lettuce cultivars (BRS Leila, BRS Lélia and BRS Mediterrânea). After finding the best concentration, a second experiment was developed to estimate the optimum dose of the biofertilizer based on the nitrogen requirement $(\mathrm{N})$ for this crop $\left(0 \mathrm{~kg} \mathrm{ha}^{-1}\right.$ of $\mathrm{N}, 50 \mathrm{~kg} \mathrm{ha}^{-1}$ of $\mathrm{N}, 100 \mathrm{~kg} \mathrm{ha}^{-1} \mathrm{~N}, 150 \mathrm{~kg} \mathrm{ha}^{-1} \mathrm{~N}$ and $200 \mathrm{~kg}$ ha $\left.{ }^{-1} \mathrm{~N}\right)$. The experimental design was completely randomized (DIC) with a factorial scheme. The results showed that $5 \%$ concentration of biofertilizer presented better results for the development of BRS Mediterrânea and BRS Lélia. BRS Leila presented better development when fertilized with the $10 \%$ biofertilizer concentration. The dose of $150 \mathrm{~kg} \mathrm{ha}^{-1}$ of $\mathrm{N}$ allowed a better development of lettuce and greater supply of nutrients to the plants.
\end{abstract}

Keywords: Lactuca sativa. L, Hortibio ${ }^{\circ}$, Morpho-agronomic attributes; Electrical conductivity.

Abbreviations: EC_Electric conductivity; EM_Efficient microorganism; LN_Leaf number; FM_Fresh mass; SH_Steam diameter; DM_Dry mass.

Introduction

The use of biofertilizers has become increasingly important in the agricultural sector. In addition to provide nutrients for crops, they increase the productivity of onion (Abbasniayzare et al., 2012), rice (Kantachote et al., 2016), pepper (Oliveira et al., 2014), barley (Islas-Valdez et al., 2015) and wheat (Fallah Nosratabad et al., 2017). They also present great potential to conserve soil health and quality, acting in the cycling of nutrients and consequently on sustainability of the production systems (Bhardwaj et al., 2014).

The biofertilizers are a group of substances from natural origin resulting from changes in organic compounds due to the existing microbial action. This microorganisms present in the biofertilizers may be involved in several soil processes, such as organic matter decomposition, soil structure maintenance and nutrient mobilization that contribute to better rooting of the plants (Schütz et al., 2018). The use of biofertilizers from organic wastes of agro-industrial activities is becoming more frequent and it is possible to consider a viable path for recycling, representing a sustainable opportunity for the management of large quantities of waste (Xu and Gleen, 2018). However, the use of biofertilizers in agriculture should be accompanied by appropriate management. Injury caused by application of bovine biofertilizers, associated with saline water or not, has been previously reported on lettuce and maize (Hasaneen et al., 2009; Inoue et al., 2011). According to Manyuchi et al. (2013), consequences such as the reduction of $\mathrm{N}$ and $\mathrm{P}$ availability may also be associated with the use of very high biofertilizer doses.

The increase in EC is especially important for crops susceptible to this variable, such as lettuce. Lettuce shows better development when the EC is around $1 \mathrm{dS} \mathrm{m}^{-1}$ (Seo et al., 2009). An increase in EC can cause damage to the rhizosphere cell wall (Munns, 2005) and imbalance nutrient absorption (AbouHadid et al., 1996), increasing the osmotic pressure of water in 
plant cells which causes reduced production (Alves et al., 2017). Additionally, the genetic potential of cultivars with different nutritional requirements should not be overlooked, where some genotypes require fewer nutrients for their cultivation. All aspects mentioned have an influence not only on the productivity of agricultural crops, but also strongly related to their environmental sustainability. This subject is currently of great relevance.

Embrapa developed an aerobic biofertilizer containing raw materials such as blood meal, rice bran, castor meal, bone meal, crushed seeds, wood ash, concentrated sugarcane extract and corn meal. This biofertilizer has been used in both organic and conventional agriculture, especially in leaf vegetables crops such as lettuce.

The hypothesis is that, the use of concentrated solutions of the biofertilizer causes increase of electrical conductivity and consequently damages the cultures. Therefore, it is necessary to establish fertilization management to improve crop yields, especially in organic agriculture. The effects of this biofertilizer on different individual behavior of lettuce cultivars should be better understood. All the above-mentioned aspects, associated with the frequent heterogeneity of crop yields are frequently observed in organic agriculture. They also require better organic inputs management.

The aim of this work was to define concentrations and doses of some biofertilizers and their management. For this purpose, a non-commercial aerobic biofertilizer was applied on three Brazilian lettuce cultivars, and consequently to improve organic lettuce yields in the country.

\section{Results and discussion}

\section{First experiment: Effect of different concentrations of aerobic biofertilizer on three lettuce cultivars}

For the fresh mass (FM), the factors biofertilizer concentration and cultivar type interacted significantly (Table 1). Fresh mass production in the cultivars BRS Lélia and BRS Mediterrânea was 354.38 to $361.25 \mathrm{~g} \mathrm{plant}^{-1}$ at the concentration of $5 \%$, differing from the cultivar BRS Leila which had the highest fresh mass, $327.3 \mathrm{~g} \mathrm{plant}^{-1}$ at the $10 \%$ concentration. This result may be related to a possible higher tolerance of salinity present in BRS Leila, since the $10 \%$ solution had an EC of $3.2 \mathrm{dS}$ $\mathrm{m}^{-1}$ while the $5 \%$ solution had an EC of $2.5 \mathrm{dS} \mathrm{m} \mathrm{m}^{-1}$. This information is suitable for future lettuce breeding studies.

For the leaf number (LN), a significant interaction between the evaluated factors was also recorded. A higher number of leaves were observed for the BRS Leila cultivar compared to BRS Lélia and Mediterrânea when fertilized with a solution containing $10 \%$ of the biofertilizer. Again, this demonstrates a possible better adaptation of BRS Leila to the aforementioned concentration. Only BRS Leila presented higher LN when submitted to treatment with the $10 \%$ biofertilizer solution. The BRS Mediterrânea cultivar presented better results when fertilized with a solution containing $5 \%$ of the biofertilizer. In turn, BRS Lélia presented different behavior, with better results recorded for concentrations of $5 \%, 15 \%$ and $20 \%$. It is possible that this last result is related to possible experimental errors or non-uniformity of the cultivar in question.
For the dry matter (DM) there was no significant interaction between the evaluated factors. Only the different biofertilizer concentrations presented effects on this attribute (Table 2). At the concentrations of 5 and $10 \%$, higher DM values were obtained.

In general, the extreme biofertilizer concentrations ( 0 and $100 \%)$ triggered the worst results for all evaluated morphoagronomic attributes. These results demonstrate that for the evaluated cultivars the biofertilizer is a beneficial input for lettuce nutrition, but in high concentrations the high saline effect can limit development of this crop.

$\mathrm{Xu}$ and Mou (2015), worked on a group of 178 cultivars and germplasm accessions after pre-selection from 3800 lettuce genotypes. They verified a great difference in sensitivity to salinization, confirming the relevance of potentially more tolerant materials. In a previous study on romaine lettuce, the existence of varieties less sensitive to high electrical conductivity values of the substrate without compromising the aerial part was observed $\left(2.44 \mathrm{dS} \mathrm{m}^{-1}\right)$, (Garmendia and Mangas, 2014). Shannon and Grieve (1999) highlighted the existence of differences between lettuce cultivars regarding tolerance to saline media.

The analyzed phytotechnical variables were significantly affected by application of the aerobic biofertilizer. In general, the results indicate that the concentrations of 5 and $10 \%$ are those most effective for the evaluated cultivars. Decreased production at higher concentrations ( $>15 \%$ ) may be associated with the high electrical conductivity of the biofertilizer. The same behavior has been observed for other vegetables, such as tomato, which presented reduced plant height and fewer fruits when higher concentrations of biofertilizer produced from algae extractd (Garcia-Gonzalez and Sommerfeld, 2016).

The higher biofertilizer concentrations induced negative effects on development of the three curly lettuce cultivars and the symptoms were similar to those noted in salinization process and nutrient deficiency as murderous, tip burn and root decay. This may be attributed to stress generated by increased osmotic potential in the growth medium (Munns, 2005), which may have caused nutritional disturbances and consequently low crop productivity (Grattan and Grieve, 1999). These results are comparable to those obtained by Kohler et al. (2009) who submitted lettuce to different levels of salt stress, observing reduced growth and productivity with increasing salt concentration. Turhan et al. (2014) also obtained lower DM percentages when the EC of irrigation water ranged from 3 to $6 \mathrm{dS} \mathrm{m}^{-1}$. Values similar to those observed for the different biofertilizer solutions were used in the present study.

Nutrient absorption by the different curly lettuce cultivars was affected by the difference of the biofertilizer concentrations $(p<0.05)$. For $\mathrm{N}, \mathrm{K}, \mathrm{Ca}$, and $\mathrm{S}$ absorption there was a significant interaction between the effects of the biofertilizer concentration and the cultivars studied (Table 3 ).

The $\mathrm{cv}$. BRS Leila presented the highest $\mathrm{N}$ accumulations at concentrations of 5 and $10 \%$ (127.72 and $108.85 \mathrm{~kg} \mathrm{ha}^{-1}$, respectively). The BRS Mediterrânea showed similar behavior, at higher levels of $\mathrm{N}$ absorption when solutions with biofertilizer concentrations of 5 and $10 \%$ were used. However, for BRS Lélia no differences in $\mathrm{N}$ absorption were observed in 
response to the different biofertilizer concentrations. Furthermore, among the cultivars BRS Lélia was that which presented lowest $\mathrm{N}$ absorption when exclusively fertilized with the $5 \%$ biofertilizer solution. The BRS Mediterrânea cultivar also showed lower $\mathrm{N}$ absorption when compared to the other cultivars for fertilization with a solution containing $20 \%$ of the biofertilizer.

Considering the effect of different concentrations on the absorption of $\mathrm{K}$ and $\mathrm{Ca}$ by the genotypes, higher values were observed when BRS Mediterrânea when fertilized with a solution containing $5 \%$ of the biofertilizer. The cultivar BRS Leila presented higher $\mathrm{Ca}$ absorption values when fertilized with solutions containing 5 to $20 \%$ of the biofertilizer, demonstrating a potentially greater tolerance to the higher EC values. However, no effect of biofertilizer concentrations on $\mathrm{K}$ absorption was observed for the cultivar BRS Lélia. Regarding the comparison between cultivars, a significant effect on $\mathrm{K}$ absorption was observed only when the solution contained $5 \%$ of the biofertilizer. In this case, the BRS Lélia presented reduced absorption of this nutrient compared to the two other materials tested.

Comparison between the biofertilizer concentrations used for each of the cultivars showed that the absorption of $\mathrm{S}$ was higher when solutions containing 5 and $20 \%$ of biofertilizer were used on BRS Leila. The BRS Mediterrânea presented higher $\mathrm{S}$ absorption when the solution contained $5 \%$ biofertilizer. No effect of the biofertilizer concentration on $\mathrm{S}$ absorption by BRS Lélia was observed. Comparison between the genetic materials showed that when a solution containing $5 \%$ of the biofertilizer was used, BRS Lélia showed the lowest absorption of $\mathrm{S}$ when compared to the two other cultivars, while the solution containing $20 \%$ of the biofertilizer resulted in lowest absorption of this chemical element by BRS Mediterrânea.

Among the evaluated nutrients, only $\mathrm{P}$ and $\mathrm{Mg}$ showed no significant interaction of concentrations and cultivars. Only effects of the concentrations on absorption of these nutrients were observed (Table 4). The results infer that the concentrations of 5, 10 and $15 \%$ favored absorption of $P$, while the concentration of $5 \%$ promoted greater absorption of $\mathrm{Mg}$.

In general, it was possible to verify a strong influence of the genotypes on nutrient absorption. It should be noted that BRS Leila, presented the best productivity when fertilized with a solution containing twice of biofertilizer concentration ( $10 \%$ vs. $5 \%)$, and promoted greater nutrient absorption in a wider range of biofertilizer concentrations. This fact may be related to a possible greater tolerance of this cultivar to salinization, since the more concentrated solutions presented higher measured EC values than less concentrated solutions. The BRS Mediterrânea presented higher nutrient absorption predominantly when the solution contained $5 \%$ biofertilizer. The same concentration promoted better production indices for this cultivar. Finally, the lack of a response from BRS Lélia regarding nutrient absorption is noteworthy, even when the absolute values are substantially different, which may be related to greater non-uniformity observed for this cultivar during the experiment.
The results related to nutrient absorption by plants, with the exception of N. Lopes et al. (2003) reported lower values on five lettuce genotypes. These results may be related to a slower nutrient supply potential of the biofertilizer when compared with mineral fertilizers, while its long-term effect may be more important, especially when producing very shortcycle agricultural crops such as lettuce. However, there is potential for better results, especially if fertilization management is associated with improvements in the production system with medium- and long-term experiments. The low nutrient absorptions observed for the highest biofertilizer concentrations, especially when the plants were fertilized with the biofertilizer in natura $(100 \%)$, which may be related to saline stress. Previous studies have shown that highly saline media can increase $\mathrm{Na}, \mathrm{K}, \mathrm{Ca}$ and $\mathrm{Mg}$ ratios, leading to an imbalance in the absorption and translocation of these nutrients (Munns, 2005).

The increased concentration of $\mathrm{Na}$ and $\mathrm{Cl}$ ions can lead to the occurrence of $\mathrm{N}$ deficiencies due to the difficulty of absorbing $\mathrm{NO}_{3}{ }^{-}$ions (Grattan and Grieve, 1999). The absorption and translocation of $\mathrm{Ca}^{2+}$ and $\mathrm{K}^{+}$in lettuce plants were decreased, when they were subjected to saline environments (Kohler et al., 2009). The same behavior was observed for P. In this case, high salinity levels resulted in a decrease in transport of $P$ stored in the root vacuoles (Martinez et al., 1996). Grattam and Grieve (1999) observed that the performance of lettuce may be adversely affected by nutritional disturbances induced by salinity, which consequently reduced the $P$ concentration in the plant tissue without presenting physical evidence of $P$ deficiency.

\section{Second experiment: Effect of the different doses of aerobic biofertilizer in the production of three cultivars of curly} lettuce

In general, the productivity values obtained in this experiment were lesser than those obtained in the first one. These values probably were influenced by the higher temperatures registered and the generalized occurrence of sclerotinia rot at the beginning of the experiment. No significant interaction was observed between the cultivars and the doses evaluated on the morpho-agronomic attributes of lettuce (Table 5). There were also no effects of the cultivars on these attributes. However, the biofertilizer doses significantly influenced the development of lettuce, indicating alterations of the attributes $\mathrm{FM}, \mathrm{DM}$ and $\mathrm{LN}$.

The biofertilizer dose corresponding to $150 \mathrm{~kg} \mathrm{ha}^{-1}$ of $\mathrm{N}$ resulted in the highest values of FM, DM and LN; therefore, this dose presented the best lettuce production results. Use of the dose of $200 \mathrm{~kg} \mathrm{ha}^{-1}$ of $\mathrm{N}$ resulted in FM and $\mathrm{LN}$ values equal to the dose of $150 \mathrm{~kg} \mathrm{ha}^{-1}$ of $\mathrm{N}$. However, the DM values observed for the higher dose were lower than those, when the $150 \mathrm{~kg} \mathrm{ha}^{-1}$ was used. Dry mass is an important attribute since it represents the solid content in the plant. The attributes of stem diameter and height were not modified in function of the different biofertilizer doses. 
Table 1. Response of the fresh mass, leaf number, stem diameter and stem height of three curly lettuce cultivars subjected to five different aerobic biofertilizer concentrations.

\begin{tabular}{|c|c|c|c|c|c|c|}
\hline \multirow[t]{2}{*}{$\begin{array}{l}\text { Hortbio }^{\circ} \\
\text { concentration }\end{array}$} & $\begin{array}{l}0 \\
\% \\
\end{array}$ & 5 & 10 & 15 & 20 & 100 \\
\hline & \multicolumn{6}{|l|}{ FM (g plant ${ }^{-1}$ ) } \\
\hline Leila & 138.60 a C & 198.15 b B & 327.33 a A & 224.91 a B & 221.85 a B & 193.85 a B \\
\hline Lélia & 178.67 a C & 354.38 a A & $217.63 \mathrm{~b} \mathrm{C}$ & 278.05 a B & 264.33 a B & 215.63 a C \\
\hline \multirow[t]{2}{*}{ Mediterrânea } & 190.75 a B & 361.25 a A & $225.43 b$ B & 232.18 a B & 198.05 a B & 173.50 a B \\
\hline & LN & & & & & \\
\hline Leila & 25.25 a B & 29.75 a A & 31.75 a A & 27.75 a B & 27.00 a B & 27.50 a B \\
\hline Lélia & 24.75 a B & 30.50 a A & 27.25 b B & 30.50 a A & 29.25 a A & 24.75 a B \\
\hline \multirow[t]{2}{*}{ Mediterrânea } & 27.25 a B & 34.25 a A & $26.50 \mathrm{~b} \mathrm{~B}$ & 26.25 a B & 27.25 a B & 24.75 a B \\
\hline & $\mathrm{SD}(\mathrm{cm})$ & & & & & \\
\hline Leila & 1.88 a B & $2.10 \mathrm{~b} \mathrm{~A}$ & 2.36 a A & 2.02 a A & 1.88 a B & 1.62 a B \\
\hline Lélia & 1.90 a B & $2.05 \mathrm{~b} \mathrm{~A}$ & 1.78 b B & 2.23 a A & 2.05 a A & 1.66 a B \\
\hline \multirow[t]{2}{*}{ Mediterrânea } & 1.91 a B & 2.42 a A & $1.72 \mathrm{~b} \mathrm{~B}$ & 2.05 a B & 1.89 a B & 1.88 a B \\
\hline & $\mathrm{SH}(\mathrm{cm})$ & & & & & \\
\hline Leila & 3.50 a B & $4.5 \mathrm{~b} \mathrm{~B}$ & 5.50 a $A$ & 4.37 a B & 4.50 a B & 3.97 a B \\
\hline Lélia & 4.00 a B & 5.8 a A & $4.40 \mathrm{~b} \mathrm{~B}$ & 5.50 a A & 5.50 a A & 4.25 a B \\
\hline Mediterrânea & 4.25 a B & 5.5 a A & 4.37 b B & 4.62 a B & 4.25 a B & 3.38 a B \\
\hline
\end{tabular}

Table 2. Response of the dry mass of three curly lettuce cultivars to five different aerobic biofertilizer concentrations.

\begin{tabular}{lc}
\hline $\begin{array}{l}\text { Concentrations } \\
\%\end{array}$ & $\begin{array}{c}\text { DM } \\
\left(\text { g plant }^{-1}\right)\end{array}$ \\
\hline 0 & $14.94 \mathrm{~b}$ \\
5 & $21.10 \mathrm{a}$ \\
10 & $17.96 \mathrm{a}$ \\
15 & $17.88 \mathrm{a}$ \\
20 & $15.49 \mathrm{~b}$ \\
100 & $13.12 \mathrm{~b}$ \\
CV (\%) & 20.3 \\
\hline
\end{tabular}

Means followed by the same lower-case letters are not different according to the Scott-Knott test $(p<0.05)$.

Table 3. Absorption of nutrients in the three curly lettuce cultivars in response to different concentrations of an aerobic biofertilizer.

\begin{tabular}{|c|c|c|c|c|c|c|}
\hline $\begin{array}{l}\text { Hortbio } \\
\text { concentrations }\end{array}$ & $\begin{array}{l}0 \\
\% \\
\end{array}$ & 5 & 10 & 15 & 20 & 100 \\
\hline \multicolumn{7}{|c|}{ Absorption of nutrients } \\
\hline \multicolumn{7}{|c|}{$\mathrm{N}\left(\mathrm{kg} \mathrm{ha}^{-1}\right)$} \\
\hline Leila & 33.78 a C & 127.72 a $A$ & 108.85 a $\mathrm{A}$ & 86.41 a B & 77.85 a B & 83.80 a B \\
\hline Lélia & 56.85 a $A$ & $93.63 \mathrm{~b} \mathrm{~A}$ & 83.86 a $\mathrm{A}$ & 82.07 a $A$ & 84.97 a A & 69.35 a $A$ \\
\hline Mediterrânea & 59.83 a B & 109.70 a A & 88.77 a $\mathrm{A}$ & 76.00 a B & 51.53 b B & 64.52 a B \\
\hline \multicolumn{7}{|l|}{$\mathrm{K}\left(\mathrm{kg} \mathrm{ha}^{-1}\right)$} \\
\hline Leila & 21.64 a B & 43.80 a A & 31.18 a A & 36.54 a $A$ & 33.73 a $A$ & 25.55 a B \\
\hline Lélia & 26.79 a A & $28.24 \mathrm{~b} \mathrm{~A}$ & 32.39 a A & 27.77 a A & 32.56 a A & 26.19 a A \\
\hline Mediterrânea & 25.18 a C & 54.81 a A & 39.65 a B & 29.40 a C & 25.11 a C & 22.66 a C \\
\hline \multicolumn{7}{|l|}{ Ca $\left(k g ~ h a ~^{-1}\right)$} \\
\hline Leila & 9.67 a B & 18.57 a $\mathrm{A}$ & 15.34 a $A$ & 15.47 a $A$ & 14.75 a $\mathrm{A}$ & 11.22 a B \\
\hline Lélia & 11.61 a A & $11.38 \mathrm{~b} \mathrm{~A}$ & 11.77 a $A$ & 11.84 a $\mathrm{A}$ & 12.86 a $\mathrm{A}$ & 9.25 a A \\
\hline Mediterrânea & 12.19 a B & 18.63 a $A$ & 13.05 a B & 13.03 a $B$ & 10.21 a B & 9.19 a B \\
\hline \multicolumn{7}{|l|}{$S\left(\mathrm{~kg} \mathrm{ha}^{-1}\right)$} \\
\hline Leila & 2.26 a B & 4.84 a $\mathrm{A}$ & 4.93 a A & 3.84 a A & 4.11 a $A$ & 4.17 a $A$ \\
\hline Lélia & 3.09 a A & $3.86 \mathrm{~b} \mathrm{~A}$ & 3.39 a A & 3.94 a A & 3.85 a A & 3.05 a A \\
\hline Mediterrânea & 3.15 a B & 5.81 a A & 4.21 a B & 3.99 a $B$ & $2.36 \mathrm{~b} \mathrm{~B}$ & 3.02 a B \\
\hline
\end{tabular}


Table 4. Absorption of $\mathrm{P}$ and $\mathrm{Mg}$ by lettuce cultivars in response to different aerobic biofertilizer concentrations.

\begin{tabular}{|c|c|c|}
\hline \multirow{3}{*}{$\begin{array}{l}\text { Concentration } \\
\%\end{array}$} & \multicolumn{2}{|c|}{ Absorption of nutrients } \\
\hline & $\mathrm{P}$ & $\mathrm{Mg}$ \\
\hline & \multicolumn{2}{|c|}{$\left(\mathrm{kg} \mathrm{ha}^{-1}\right)$} \\
\hline 0 & $1.85 \mathrm{c}$ & $2.19 \mathrm{c}$ \\
\hline 5 & $4.11 \mathrm{a}$ & $3.26 \mathrm{a}$ \\
\hline 10 & 3.49 a & $2.77 \mathrm{~b}$ \\
\hline 15 & $3.36 \mathrm{a}$ & $2.73 \mathrm{~b}$ \\
\hline 20 & $2.69 \mathrm{~b}$ & $2.33 \mathrm{C}$ \\
\hline 100 & $2.61 \mathrm{~b}$ & $2.08 \mathrm{c}$ \\
\hline CV (\%) & 28.32 & 20.02 \\
\hline
\end{tabular}

Means followed by the same letters, lower-case in the column, do not differ according to the Scott-Knott test $(p<0.05)$

Table 5. Response of the fresh mass, dry mass, leaf number, stem diameter and stem height of the curly lettuce cultivated in five different aerobic biofertilizer doses.

\begin{tabular}{|c|c|c|c|c|c|}
\hline $\begin{array}{l}\text { Biofertilizer doses } \\
\left(\mathrm{kg} \mathrm{N} \mathrm{ha}^{-1}\right)\end{array}$ & $\begin{array}{l}\text { FM } \\
\left(\text { g planta }^{-1}\right)\end{array}$ & DM & $\mathrm{LN}$ & $\begin{array}{l}\text { SD } \\
(\mathrm{cm})\end{array}$ & $\mathrm{SH}$ \\
\hline 0 & $90.60 \mathrm{c}$ & $5.54 \mathrm{~b}$ & $13.30 \mathrm{~b}$ & $1.42 \mathrm{a}$ & $5.26 \mathrm{a}$ \\
\hline 50 & $98.12 \mathrm{c}$ & $5.84 \mathrm{~b}$ & $14.80 \mathrm{a}$ & $1.37 \mathrm{a}$ & $5.37 \mathrm{a}$ \\
\hline 100 & $103.86 \mathrm{~b}$ & $6.03 \mathrm{~b}$ & $15.70 \mathrm{a}$ & $1.51 \mathrm{a}$ & 5.49 a \\
\hline 150 & $110.90 \mathrm{a}$ & $6.83 a$ & $16.20 \mathrm{a}$ & $1.41 \mathrm{a}$ & $5.65 \mathrm{a}$ \\
\hline 200 & $113.49 \mathrm{a}$ & $5.85 \mathrm{~b}$ & $16.00 \mathrm{a}$ & $1.37 \mathrm{a}$ & $5.90 \mathrm{a}$ \\
\hline CV \% & 8.96 & 13.90 & 10.70 & 13.80 & 19.30 \\
\hline
\end{tabular}

Means followed by the same letter, lower-case in the column do not differ according to the Scott-Knott test $(p<0.05)$.

Table 6. Nutrient absorption by curly lettuce plants treated with five biofertilizer doses.

\begin{tabular}{lllllll}
\hline $\begin{array}{l}\text { Biofertilizer doses } \\
\left(\mathrm{kg} \mathrm{N} \mathrm{ha}^{-1}\right)\end{array}$ & $\begin{array}{l}\mathrm{N} \\
\left(\mathrm{kg} \mathrm{ha}^{-1}\right)\end{array}$ & $\mathrm{P}$ & $\mathrm{K}$ & $\mathrm{Ca}$ & $\mathrm{Mg}$ & $\mathrm{S}$ \\
\hline 0 & $37.39 \mathrm{~b}$ & $1.20 \mathrm{~b}$ & $14.65 \mathrm{a}$ & $5.86 \mathrm{~b}$ & $0.98 \mathrm{a}$ & $1.90 \mathrm{a}$ \\
50 & $40.64 \mathrm{~b}$ & $1.36 \mathrm{a}$ & $16.66 \mathrm{a}$ & $6.65 \mathrm{~b}$ & $1.09 \mathrm{a}$ & $2.11 \mathrm{a}$ \\
100 & $42.33 \mathrm{~b}$ & $1.40 \mathrm{a}$ & $16.45 \mathrm{a}$ & $7.31 \mathrm{a}$ & $1.15 \mathrm{a}$ & $2.11 \mathrm{a}$ \\
150 & $49.99 \mathrm{a}$ & $1.47 \mathrm{a}$ & $18.60 \mathrm{a}$ & $7.66 \mathrm{a}$ & $1.22 \mathrm{a}$ & $2.32 \mathrm{a}$ \\
200 & $44.93 \mathrm{a}$ & $1.55 \mathrm{a}$ & $16.17 \mathrm{a}$ & $7.32 \mathrm{a}$ & $1.10 \mathrm{a}$ & $2.23 \mathrm{a}$ \\
CV\% & 14.80 & 18.3 & 18.4 & 16.25 & 17.00 & 18.70 \\
\hline
\end{tabular}

Means followed by the same letters do not statistically differ according to the Scott-Knott test ( $p<0.05)$

Table 7. Soil chemical characteristics of both experiments.

\begin{tabular}{lll}
\hline Chemical characteristics & Soil ${ }^{\text {st }}$ experiment & Soil $2^{\text {nd }}$ experiment \\
\hline $\mathrm{OM}\left(\mathrm{g} \mathrm{kg}^{-1}\right)$ & 18.7 & 21.4 \\
$\mathrm{P}\left(\mathrm{g} \mathrm{kg}^{-1}\right)$ & 0.0032 & 0.0038 \\
$\mathrm{~K}\left(\mathrm{~g} \mathrm{~kg}^{-1}\right)$ & 0.278 & 0.259 \\
$\mathrm{Na}\left(\mathrm{g} \mathrm{kg}^{-1}\right)$ & 0.029 & 0.033 \\
$\mathrm{Ca}\left(\mathrm{cmol}_{\mathrm{c}} \mathrm{kg}^{-1}\right)$ & 4.2 & 4.4 \\
$\mathrm{Mg}\left(\mathrm{cmol}_{\mathrm{c}} \mathrm{kg}^{-1}\right)$ & 1.2 & 1.2 \\
$\mathrm{~S}\left(\mathrm{~g} \mathrm{~kg}^{-1}\right)$ & 0.0121 & 0.0104 \\
$\mathrm{Al}\left(\mathrm{cmol}_{\mathrm{c}} \mathrm{dm}^{-3}\right)$ & 0 & 0 \\
$\mathrm{H}+\mathrm{Al}\left(\mathrm{cmol}_{\mathrm{c}} \mathrm{dm}^{-3}\right)$ & 3.4 & 3.2 \\
$\mathrm{pH}\left(\mathrm{H}_{2} \mathrm{O}\right)$ & 5.8 & 5.4 \\
$\mathrm{~B}\left(\mathrm{mg} \mathrm{dm}^{-3}\right)$ & 0.07 & 0.07 \\
$\mathrm{Cu}\left(\mathrm{mg} \mathrm{dm}^{-3}\right)$ & 1 & 1.2 \\
$\mathrm{Fe}\left(\mathrm{mg} \mathrm{dm}^{-3}\right)$ & 30.8 & 36.8 \\
$\mathrm{Mn}\left(\mathrm{mg} \mathrm{dm}^{-3}\right)$ & 71.6 & 60.9 \\
$\mathrm{Zn}\left(\mathrm{mg} \mathrm{dm}^{-3}\right)$ & 2.1 & 2.5 \\
\hline
\end{tabular}

Table 8. Chemical characteristics of the biofertilizer Hortbio ${ }^{\bullet}$.

\begin{tabular}{|c|c|c|c|c|c|c|c|c|c|c|c|c|c|c|c|c|c|}
\hline $\mathrm{pH}$ & $\mathrm{EC}$ & TN & $P$ & K & $\mathrm{Mg}$ & $S$ & $\mathrm{Ca}$ & B & $\mathrm{Cu}$ & $\mathrm{Fe}$ & $\mathrm{Mn}$ & $\mathrm{Zn}$ & As & $\mathrm{Cd}$ & $\mathrm{Ba}$ & $\mathrm{Ni}$ & $\mathrm{Pb}$ \\
\hline$\left(\mathrm{H}_{2} \mathrm{O}\right)$ & $\left(\mathrm{dS} . \mathrm{m}^{1}\right)$ & --- & ---.. & $-(\mathrm{g} \mathrm{I}$ & ) ---. & ----- & & -- & & - & 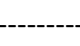 & ----- ( & $\left.\mathrm{g} \mathrm{dm}^{-3}\right)$ & - & & - & -- \\
\hline 6 & 5.45 & 4.3 & 0.2 & 1.4 & 0.9 & 0.23 & 2.6 & 1.5 & 12.6 & 133.5 & 10.3 & 1.13 & $<0.01$ & $<0.01$ & $<0.01$ & $<0.01$ & $<0.01$ \\
\hline
\end{tabular}

TN: total nitrogen; EC: electrical conductivity. 
Table 9. Electrical conductivity of the aerobic biofertilizer quantified in solutions of different concentrations.

\begin{tabular}{|c|c|c|c|c|c|}
\hline $\begin{array}{l}\text { Hortbio concentration } \\
\text { (\%) }\end{array}$ & 5 & 10 & 15 & 20 & 100 \\
\hline $\mathrm{EC} \mathrm{dS} \mathrm{m^{-1 }}$ & 2.5 & 3.2 & 3.8 & 4 & 5.45 \\
\hline \multirow{3}{*}{ Solution preparation } & $10.5 \mathrm{~mL}$ Hortbio & $10.5 \mathrm{~mL}$ Hortbio & $10.5 \mathrm{~mL}$ Hortbio & $10.5 \mathrm{~mL}$ Hortbio & $10.5 \mathrm{~mL}$ Hortbio \\
\hline & + & + & + & + & + \\
\hline & $220 \mathrm{~mL} \mathrm{H} \mathrm{H}_{2}$ & $110 \mathrm{~mL} \mathrm{H} \mathrm{H}_{2} \mathrm{O}$ & $70 \mathrm{~mL} \mathrm{H} \mathrm{O}_{2} \mathrm{O}$ & $50 \mathrm{~mL} \mathrm{H}_{2} \mathrm{O}$ & $0 \mathrm{~mL} \mathrm{H} \mathrm{H}_{2} \mathrm{O}$ \\
\hline
\end{tabular}

Similar FM production values were observed by Baslam et al. (2011) using mycorrhizal fungi for production of three different lettuce cultivars. These authors obtained FM values ranging from 87 to $150 \mathrm{~g} \mathrm{plant}^{-1}$ using experimental conditions similar to those of the present work. Hasan et al. (2017), tested different nitrogen fertilizer doses also under similar conditions and obtained a fresh mass weight of $115 \mathrm{~g}$ at 50 DAT for the highest $\mathrm{N}$ dose $\left(150 \mathrm{~kg} \mathrm{ha}^{-1}\right)$. Chiconato et al. (2014), applied bovine biofertilizer in crisp lettuce cv. Vera and reported higher fresh mass values, around $308 \mathrm{~g}$, when applied $90 \mathrm{~m}^{3}$ $\mathrm{ha}^{-1}$ of this compound. The highest dose used in their work $\left(150 \mathrm{~m}^{3} \mathrm{ha}^{-1}\right)$ caused a decrease in production $(290 \mathrm{~g})$. Chatterjee (2015) evaluated doses of vermicompost plus biofertilizer on the production of iceberg lettuce and found higher values for the fresh mass (412 g) and leaf number (18). Colla et al. (2015) tested a biostimulant and found similar weights of DM in romaine lettuce (4.8 g). Beninni et al. (2005) compared hydroponic and conventional cultivation of curly lettuce cv. Veronica and found values for fresh mass equal to $160 \mathrm{~g}$ and $279 \mathrm{~g}$, and the DM weights varied from $6.81 \mathrm{~g}$ and $12.96 \mathrm{~g}$ for each production system, respectively.

Application of $\mathrm{N}$ doses of 150 and $200 \mathrm{~kg} \mathrm{ha}^{-1}$ of the biofertilizer presented higher values of the FM, DM and LN attributes, when compared to the control treatment. This behavior has already been observed in other studies and generally shows that the use of biofertilizer promotes greater productivity in lettuce (Saeed et al., 2015), cucumber (Duc et al., 2017), tomato (Colla et al., 2015) and strawberry (PeŠaković et al., 2013). In addition to the supply of nutrients, growth promoting microorganisms (PGPR) is another factor that can cause good results. They contribute to $\mathrm{N}$ fixation, $\mathrm{P}$ solubilization, nutrient absorption and production of plant hormones that encourage root system development (Schütz et al., 2018). Bomfim (2016) characterized the microorganisms of Hortbio and found a great diversity of bacteria, yeasts and fungi, several of which were PGPR.

Regarding the effect of the cultivars and doses on nutrient absorption, we observed that the interaction between these two factors was not significant for any evaluated attribute (Table 6). There was also no isolated effect of the cultivars on absorption of the nutrients evaluated. However, the dose factor had a significant effect on N, P and Ca absorption by the lettuce plants. Absorption of $\mathrm{K}, \mathrm{Mg}$ and $\mathrm{S}$ was not affected by the different biofertilizer doses used.

The doses of $150 \mathrm{~kg} \mathrm{ha}^{-1}$ and $200 \mathrm{~kg} \mathrm{ha}^{-1}$ promoted $\mathrm{N}$ absorption. Absorption of $\mathrm{P}$ was positively affected by biofertilization, presenting the highest values when doses between 50 and $200 \mathrm{~kg} \mathrm{ha}^{-1}$ were used. Values of Ca absorption were higher when doses within a range of 100 and $200 \mathrm{~kg} \mathrm{ha}^{-1}$ of $\mathrm{N}$ were used.
The results infer a potential positive relationship between obtaining better production and nutrient absorption, especially N, P and Ca. Flores-Félix et al. (2013), used a biofertilizer inoculated with Rhizobium leguminosarum and found a nitrogen concentration of $37.2 \mathrm{~g} \mathrm{~kg}^{-1}$ in plant tissue of romaine lettuce. Farrag et al. (2016) tested different doses of conventional fertilizer along with a foliar fertilizer and recorded a concentration of $43.3 \mathrm{~g} \mathrm{~kg}^{-1}$ for this nutrient. Resende et al. (2009) observed that $\mathrm{N}$ doses higher than $120 \mathrm{~kg}$ $\mathrm{ha}^{-1} \mathrm{~N}$ applied to lettuce resulted in an increase in the $\mathrm{N}$ concentration.

Busato et al. (2016) found higher levels of $N$ in Guanandi (Calophyllum brasiliense) seedlings fertilized with the same biofertilizer in the present study plus a soluble humic extract. These authors verified that biofertilizer enriched with organic matter and microorganisms can alter the root exudation profile of acids and other organic compounds of the guanandi seedlings, increasing the supply of nutrients to the plant.

A beneficial effect of the use of biofertilizers on nitrogen absorption, as well as an improved sunflower crop yield, was observed by Shehata and El-Khawas (2003) when they tested two biofertilizers (biogen and microben) on the sunflower crop. The values obtained for concentration of the nutrients are within the range considered suitable for this crop in the harvest phase, from 3 to $5 \mathrm{~g} \mathrm{~kg}^{-1}$.

The biofertilizer used as a source of $P$ in this crop provided low $P$ concentration and consequently low absorption (1.55 kg ha $\left.{ }^{1}\right)$. Higher concentrations were observed $\left(7 \mathrm{~g} \mathrm{~kg}^{-1}\right)$ in lettuce after the use of a biofertilizer based on Rhizobium leguminosarium (Flores-Félix et al., 2013). In a hydroponic system, Lopes et al. (2003) tested six lettuce cultivars and found no significant differences between the different genotypes and $P$ accumulation, which was higher than that found in the present study $\left(3 \mathrm{~kg} \mathrm{ha}^{-1}\right)$. Studies developed by Kano et al. (2011) indicated that the highest $P$ demands for the cultivar of crisp lettuce cv. Verónica are recorded in the tasseling and flowering stages (49 to 69 DAT) that are not observed in the present study.

Khosravi et al. (2017) evaluated the P absorption of different sources of organic and mineral $P$ plus vermicompost and biofertilizer. They emphasized that the use of this product can change the chemical forms of inorganic phosphorus, which in this case caused an increase in $\mathrm{P}$ absorption by the plant. Bhadoria et al. (2009) tested the efficiency of $P$ absorption by corn and peanut subjected to solutions with different rates of $\mathrm{P}$ availability, attributing the higher $\mathrm{P}$ absorption efficiency to the root system. 


\section{Materials and methods}

\section{Plant materials}

Three emergent cultivars of curly lettuce: BRS Leila, BRS Mediterrânea and BRS Lélia were provided by Embrapa Vegetables. The lettuce plants were sown in trays of expanded polystyrene of 128 cells, conditioned in a greenhouse. The seedlings were transplanted 25 days after sowing in pots containing a volume of $0.5 \mathrm{dm}^{-3}$ of soil for each experiment.

\section{Location and description of the study area}

The experiments were carried out during sequential periods. The first experiment was carried out from June to August 2017 (in the winter, mean air temperature $20.3{ }^{\circ} \mathrm{C}$ ) and aims to determine the optimum concentration of the biofertilizer for each lettuce cultivars used because its high EC values would be causing damages to lettuce plants. The second one was carried out from September to October 2017 (in the spring, mean air temperature $24.3^{\circ} \mathrm{C}$ ) and aimed to determine the optimum dose of the biofertilizer for each lettuce cultivar. The doses proposed to evaluation were determined on biofertilizer $\mathrm{N}$ contents because this nutrient is commonly used to define fertilization recommendation in organic agriculture. Both experiments were conducted in a greenhouse located at Embrapa Hortaliças, Brasília - DF, Brazil, whose geographic coordinates are: $15^{\circ} 4647^{\prime \prime} \mathrm{S}, 47^{\circ} 55^{\prime} 47^{\prime \prime} \mathrm{W}$ and $1171 \mathrm{~m}$ elevation.

The substrate used for cultivation was prepared from a mixture of a clayey Rhodic Ferralsol (Embrapa, 2013) and rice straw. The Table 7 shows the characteristics of the initial soil technique for each experiment.

\section{Preparation of the aerobic biofertilizer}

The biofertilizer used in both experiments, whose formula is freely available to the producer and was considered a noncommercial product called $\mathrm{Hortbio}^{\circledR}$, was produced in a plastic tank with capacity of $100 \mathrm{~L}$. The materials used in biofertilizer production were: blood meal $(1.1 \mathrm{~kg})$, rice bran $(4.4 \mathrm{~kg})$, castor meal $(1.1 \mathrm{~kg})$, bone meal $(2.2 \mathrm{~kg})$, crushed seeds $(1.1 \mathrm{~kg})$, wood ash $(1.1 \mathrm{~kg})$, rapadura (concentrated sugarcane extract) $(0.55$ $\mathrm{kg}$ ) and corn meal $(0.55 \mathrm{~kg})$, enriched with $1 \mathrm{~L}$ of the Efficient Microorganisms (EM). At the end non-chlorinated water was added to a final volume of $100 \mathrm{~L}$. The final mixture was stored in a shaded and cool place with aeration for 15 min every hour, with the aid of an air compressor and a timer.

\section{Irrigation system}

The irrigation system for both experiments was designed to uniformly replenish water for all treatments, so that a previously determined water volume was applied manually. For this, five pots containing $0.5 \mathrm{dm}^{3}$ of soil were weighed. Irrigas ${ }^{\circledR}$ sensors $(15 \mathrm{kPa}$ ) were installed at $3 \mathrm{~cm}$ deep in two pots per treatment. Subsequently, water was added until the field capacity of the soil was reached, and the weight was again recorded. The amount of water needed from irrigation was defined by the difference in mass between pots containing soil at field capacity and soil in a condition immediately prior to the Irrigas ${ }^{\circledR}$ reading which indicated the need for irrigation.

\section{Conduction of first experiment: Different concentrations of aerobic biofertilizer applied to three cultivars of curly lettuce}

This experiment sought to evaluate the influence of the high electrical conductivity observed in the concentrated biofertilizer on crop development. The treatments were established in function of the $\mathrm{N}$ requirement for lettuce cultivation, which is $150 \mathrm{~kg} \mathrm{ha}^{-1}$ of $\mathrm{N}$ (Fontes, 1999), to reach a production of 21 tons per hectare. From the $\mathrm{N}$ content of the biofertilizer (Table 8) and the volume of soil contained in the pots, a calculation was performed to determine the volume to be added. This volume then was diluted in different volumes of non-chlorinated water, generating solutions with biofertilizer concentrations of $0 \%, 5 \%, 10 \%, 15 \%, 20 \%$ and $100 \%$ (Table 9). For each concentration, the volume of solution was applied integrally to each pot, ensuring that the recommended $\mathrm{N}$ demand for the crop applied in different treatments. The solutions were prepared at the time of application, which were always in the morning. In each pot, the solutions were applied around the base of the plant.

\section{Experimental design and statistical analyses}

The experiment was set up in a completely randomized design with four replications. A $3 \times 6$ factorial scheme was used (three lettuce cultivars: BRS Leila, BRS Mediterrânea and BRS Lélia and six biofertilizer concentrations: $0 \%, 5 \%, 10 \%, 15 \%, 20 \%$, $100 \%)$. Normality of the data was then tested and the data was submitted to analysis of variance (ANOVA) by the F-test at $5 \%$ probability. The averages were compared by the Scott-Knott test at the same level of significance $(P<0.05)$.

Conduction of second experiment: Different doses of aerobic biofertilizer applied to three cultivars of curly lettuce

In this experiment, the effects of different biofertilizer doses on three cultivars of curly lettuce were evaluated. These doses were defined based on the supply of $\mathrm{N}$ by the biofertilizer. The doses were: $0,50,100,150$ and $200 \mathrm{~kg} \mathrm{ha}^{-1}$ of $\mathrm{N}$, calculated according to the $\mathrm{N}$ content in the biofertilizer (Table 8). The first biofertilizer application was performed six days after transplantation.

\section{Experimental design and statistical analyses}

This experiment also was set up in a completely randomized design with four replications. Different doses were tested using a $3 \times 5$ factorial scheme (three lettuce cultivars: BRS Leila, BRS Mediterrânea and BRS Lélia and five $N$ doses: $0,50,100,150$ and $200 \mathrm{~kg} \mathrm{ha}^{-1}$ of $\mathrm{N}$ ). Normality of the data was then tested and the data was submitted to analysis of variance (ANOVA) by the F-test at $5 \%$ probability. The averages were compared by the Scott-Knott test at the same level of significance $(P<0.05)$. 


\section{Laboratory analyses and irrigation system for both experiments}

The agronomic attributes evaluated were: leaf number (LN), fresh mass of the aerial part (FM), stem height (SH) and stem diameter (SD). For determination of the dry mass (DM), the samples were washed with distilled water. Then they were air dried and placed in a paper bag. Afterwards, they were placed in a forced air circulation oven at $65^{\circ} \mathrm{C}$ for $72 \mathrm{~h}$ until reaching a constant mass. The dried plants were then weighed on a digital scale with accuracy of $0.1 \mathrm{~g}$. The dried samples were ground in a Willey-type stainless steel mill, sieved and stored in glass jars. The method used to determine the macro $(\mathrm{P}, \mathrm{K}, \mathrm{Ca}, \mathrm{Mg}, \mathrm{S})$ and micronutrients $(\mathrm{B}, \mathrm{Fe}, \mathrm{Mn})$ in leaf tissue was nitro-perchloric wet digestion described by Malavolta et al. (1997). For this, $500 \mathrm{mg}$ of tissue sample was mixed with $8 \mathrm{~mL}$ of $\mathrm{HNO}_{3}, 2 \mathrm{~mL}$ of $\mathrm{HCl}$ and $2 \mathrm{~mL}$ of $\mathrm{H}_{2} \mathrm{O}_{2}$ for digestion in a microwave oven. Subsequently the digested samples were analyzed by inductively coupled plasma optical emission spectrometry ICP-OES. After each set of 20 samples, a standard Fluka Multielement solution $\left(10 \mathrm{mg} \mathrm{L}^{-1}\right)$ was used as a reference for calibrating the equipment. The quantities of accumulated nutrients were obtained by the ratio between the content of each nutrient and the dry mass of the sample. The total $\mathrm{N}$ content was obtained by digestion with sulfuric acid and hydrogen peroxide, according to the Kjeldahl method (Bremmer, 1996).

\section{Conclusion}

The cultivar BRS Leila presented greatest tolerance to the use of higher biofertilizer concentrations, presenting better results when fertilized with a solution containing $10 \%$ biofertilizer, which may be related to a possible greater tolerance to this abiotic stress or more demanding in the nutrient requirement. This information may support the planting of these cultivars in regions with salinity, such as arid, semi-arid and often flooded regions. The cultivars BRS Mediterrânea and BRS Lélia presented best development when biofertilized with a $5 \%$ solution. Solutions containing $5 \%$ or $10 \%$ of the biofertilizer tended to induce greater nutrient absorption by the plants. The dose of $150 \mathrm{~kg} \cdot \mathrm{ha}^{-1}$ promoted greatest productivity of the curly lettuce cultivars. Higher biofertilizer doses promoted increased absorption of nutrients such as N, P and Ca.

\section{References}

Abbasniayzare SK, Sedaghathoor S, Dahkaei PNM (2012) Effect of biofertilizer application on growth parameters of Spathiphyllum illusion. Agric Environ Sci. 5: 669-673.

Abou-Hadid AF, Abd-Elmoniem EM, El-Shinawy MZ, AbouElsoud M (1996) Electrical conductivity effect on growth and mineral composition of lettuce plants in hydroponic system. Acta Hortic. 434: 59-66.

Alves LS, Araújo DL, Melo Filho JS, Véras MLM, Irineu THS, Andrade R (2017) Electric conductivity levels in irrigation water and application of biofertilizer in peanut $\mathrm{Br} 1$ crops. Comun Sci. 8: 347-355.
Baslam M, Garmendia I, Goicoechea N (2011) Arbuscular mycorrhizal fungi (AMF) improved growth and nutritional quality of greenhouse-grown lettuce. J Agric Food Chem. 59: 5504-5515.

Beninni ERY, Takahashi HW, Neves CSVJ (2005) Concentration and accumulation of macronutrients in hydroponic and conventional lettuce. Semin Cien Agrar. 26: 273-282.

Bhadoria P, Samal D, Steingrobe B, Claassen N (2009) Phosphorus uptake kinetics, root-shoot relations and P-influx of groundnut and maize grown in solution culture. UC Davis: Department of Plant Sciences, California, 1-7.

Bhardwaj D, Ansari MW, Sahoo RK, Tuteja N (2014) Biofertilizers function as key player in sustainable agriculture by improving soil fertility, plant tolerance and crop productivity. Microb Cell Fact. 13: 1-10.

Bomfim CA (2016) Biofertilizante Hortbio ${ }^{\circledR}$ : Características microbiológicas e efeito na qualidade da alface. M.Sc. dissertation, Brasilia University, Brazil, p.127.

Bremmer JM (1996) Nitrogen-total in: Sparks, DL Methods of soil analysis. Part 3-Chemical methods. SSSA, Madison, Wisconsin, 1085-1121.

Busato JG, Zandonadi DB, Sousa IM, Marinho EB, Dobbss LB, Mól AR (2016) Efeito do extrato húmico solúvel em água e biofertilizante sobre o desenvolvimento de mudas de Callophyllum brasiliense. Pesqui Florest Bras. 36: 161-168.

Chatterjee R (2015) Influence of nutrient sources on growth, yield and economics of organic lettuce production under foothills of eastern Himalayan region. Emirates J Food Agric. 27: 460-462.

Chiconato DA, Galbiatti JA, Junior WM, Franco CF, Caramelo $A D$ (2014) Bovine biofertilizer and irrigation layers on lettuce development and leaf chlorophyll. Comun Sci. 5: 140-147.

Colla G, Rouphael Y, Di Mattia E, El-Nakhel C, Cardarelli M (2015) Co-inoculation of Glomus intraradices and Trichoderma atroviride acts as a biostimulant to promote growth, yield and nutrient uptake of vegetable crops. J Sci Food Agric. 95: 1706-1715.

Duc NH, Mayer Z, Pék Z, Helyes L, Posta K (2017) Combined inoculation of arbuscular mycorrhizal fungi, Pseudomonas Fluorescens and Trichoderma spp. for enhancing defense enzymes and yield of three pepper cultivars. Appl Ecol Environ Res. 15: 1815-1829.

EMBRAPA (2013) Sistema brasileiro de classificação de solos. Embrapa Sistema de Informação, Brasília.

Fallah Nosratabad AR, Etesami H, Shariati S (2017) Integrated use of organic fertilizer and bacterial inoculant improves phosphorus use efficiency in wheat (Triticum aestivum L.) fertilized with triple superphosphate. Rhizosphere. 3: 109111.

Farrag DK, El-Dein OAO, Khafagy IF (2016) Impact of spraying with Saccharomyces cerevisiae and some commercial nutrients on lettuce plant (Lactuca sativa L.) productivity and prevention of some insect pests. Int J Plant Soil Sci. 11: 1-11.

Flores-Félix JD, Menéndez E, Rivera LP, Marcos-García $M$, Martínez-Hidalgo P, Mateos PF, Martínez-Molina E, Velázquez ME, García-Fraile P, Rivas R (2013) Use of Rhizobium leguminosarum as a potential biofertilizer for Lactuca sativa and Daucus carota crops. J Plant Nutr Soil Sci. 176: 876-882. 
Garcia-Gonzalez J, Sommerfeld M (2016) Biofertilizer and biostimulant properties of the microalga Acutodesmus dimorphus. J Appl Phycol. 28: 1051-1061.

Garmendia I, Mangas VJ (2014) Comparative study of substrate-based and commercial formulations of arbuscular mycorrhizal fungi in romaine lettuce subjected to salt stress. J Plant Nutr. 37: 1717-1731.

Grattan SR, Grieve CM (1999) Salinity-mineral nutrient relations in horticultural crops. Sci Hortic. 78: 127-157.

Fontes PCR (1999) Sugestões de adubação para alface In: Ribeiro AC, Guimarães PTG, Alvarez VH. Recomendações para o uso de corretivos e fertilizantes em Minas Gerais $5^{\text {a }}$. Aproximação. Viçosa.

Hasan MR, Tahsin AKMM, Islam MN, Ali AM, Uddain J (2017) Growth and yield of lettuce (Lactuca Sativa L.) influenced as nitrogen fertilizer and plant spacing. J Agri Vet Sci. 10: 62-71.

Hasaneen MNA, Younis, ME, Tourky, SMN (2009) Salinitybiofertility interactive effects on growth, carbohydrates and photosynthetic efficiency of Lactuca sativa L. Plant Omics. 2: 60-69.

Inoue KRA, Souza CF, Matos AT, Santos, NT, Ferreira WFM (2011) Concentração de nutrientes em plantas de milho, adubadas com biofertilizantes, obtidos na digestão anaeróbia de manipueira. Eng Agric.19: 236-243.

Islas-Valdez $\mathrm{S}$, Lucho-Constantino CA, Beltrán-Hernández RI, Gómez-Mercado R, Vázquez-Rodríguez GA, Herrera JM, Jiménez-González A (2015) Effectiveness of rabbit manure biofertilizer in barley crop yield. Environ Sci Pollut Res. 24: 5731-5740.

Kano C, Cardoso All, Villas Bôas RL (2011) Acúmulo de nutrientes pela alface destinada à produção de sementes. Hortic Bras. 29: 70-77.

Kantachote D, Nunkaew T, Kantha T, Chaiprapat S (2016) Biofertilizers from Rhodopseudomonas palustris strains to enhance rice yields and reduce methane emissions. Appl Soil Ecol. 100: 154-161.

Khosravi A, Zarei M, Ronaghi A (2017) Influence of biofertilizers and phosphate sources on the phosphorus uptake of lettuce and chemical forms of phosphorus in soil. Commun Soil Sci Plant Anal. 48: 2701-2714.

Kohler J, Hernández JA, Caravaca F, Roldán A (2009) Induction of antioxidant enzymes is involved in the greater effectiveness of a PGPR versus AM fungi with respect to increasing the tolerance of lettuce to severe salt stress. Environ Exp Bot. 65: 245-252.

Lopes MC, Freier M, Matte JD, Gärtner M, Franzener G, Casimiro ELN, Sevignani A (2003) Acúmulo de nutrientes por cultivares de alface em cultivo hidropônico no inverno. Hortic Bras. 21: 211-215.

Lucini L, Rouphael Y, Cardarelli M, Canaguier R, Kumar P, Colla $G$ (2015) The effect of a plant-derived biostimulant on metabolic profiling and crop performance of lettuce grown under saline conditions. Sci Hortic. 182: 124-133.

Malavolta E, Vitti GC, Oliveira SA (1997) Avaliação do estado nutricional das plantas: princípios e aplicações. 2ed. Piracicaba: Associação Brasileira para a pesquisa da potassa e do fosfato.
Manyuchi MM, Chitambwe T, Phiri A, Muredzi P, Kanhukamwe Q (2013) Effect of vermicompost, vermiwash and application time on soil physicochemical properties. Int J Chem Environ Eng. 4: 216-220.

Martinez V, Bernstein N, Läuchli A (1996) Salt-induced inhibition of phosphorus transport in lettuce plants. Physiol Plant. 97: 118-122.

Munns R (2005) Genes and salt tolerance. New Phytol. 167: 645-663.

Oliveira JR, Gomes RLF, Araújo ASF, Marini FS, Lopes JB, Araújo RM (2014) Estado nutricional e produção da pimenteira com uso de biofertilizantes líquidos. Rev Bras Eng Agric Ambient. 18: 1241-1246.

PeŠaković M, Karaklajić-Stajić Ž, Milenković S, Mitrović O (2013) Biofertilizer affecting yield related characteristics of strawberry (Fragariaxananassa Duch.) and soil microorganisms. Sci Hortic. 150: 238-243.

Resende GM, Alvarenga MAR, Yuri JE, Souza RJ, Mota JH, Carvalho J, Júnior JC (2009) Rendimento e teores de macronutrientes em alface tipo americana em função de doses de nitrogênio e molibdênio em cultivo de verão. Ciênc Agrotec. 33: 153-163.

Saeed KS, Ahmed SA, Hassan IA, Ahmed PH (2015) Effect of bio-fertilizer and chemical fertilizer on growth and yield in cucumber (Cucumis sativus) in green house condition. Pakistan J. Biol. Sci. 18: 129-134.

Schütz L, Gattinger A, Meier M, Müller A, Boller T, Mäder $P$, Mathimaran N (2018) Improving crop yield and nutrient use efficiency via biofertilization- A global meta-analysis. Frontiers Plant Sci. 8: 1-13.

Shannon MC, Grieve CM (1999) Tolerance of vegetable crops to salinity. Sci Hortic. 78: 5-38.

Shehata MM, El-Khawas SA (2003) Effect of two biofertilizers on growth parameters, yield characters, nitrogenous components, nucleic acid content, minerals, oil content, protein profiles and DNA banding pattern of sunflower (Helianthus annus L. cv. Vedock). Pak J Biol Sci. 6: 1257-1268.

Turhan A, Kuscu H, Ozmen N, Sitki Serbeci M, Osman Demir A (2014) Effect of different concentrations of diluted seawater on yield and quality of lettuce. Chil J Agric Res. 74: 111-116.

Seo MW, Yang DS, Kays SJ, Kim J, Woo JH, Park WK (2009) Effects of nutrient solution electrical conductivity and sulfur, magnesium, and phosphorus concentration on sesquiterpene lactones in hydroponically grown lettuce (Lactuca sativa L.). Sci Hortic. 122: 369-374.

Xu C, Mou B (2015) Evaluation of lettuce genotypes for salinity tolerance. Hortic Sci. 50: 1441-1446.

$\mathrm{Xu}, \mathrm{L}$; Geelen, D (2018) Developing biostimulants from agrofood and industrial by-products. Front Plant Sci, 9: 1-25. 